Tohoku J. Exp. Med., 2005, 207, 209-216

\title{
A New Preadipocyte Cell Line, AP-18, Established from Adult Mouse Adipose Tissue
}

\author{
Hideyuki Doi, Nakui Masaki, Hitoshi Takahashi, Hiromichi Komatsu, \\ KeISEI Fujimori and Susumu SATomi \\ Division of Advanced Surgical Science and Technology, Graduate School of \\ Medicine Tohoku University, Sendai, Japan
}

Doi, H., Masaki, N., Takahashi, H., Komatsu, H., Fujimori, K. and Satomi, S. A New Preadipocyte Cell Line, AP-18, Established from Adult Mouse Adipose Tissue. Tohoku J. Exp. Med., 2005, 207 (3), 209-216 — Establishing preadipocyte cell lines from mature adipose tissues could help lead to a better understanding of adipogenesis. We have established a unique preadipocyte cell line, AP-18, derived from the subepidermal layer of ear skin from an adult $\mathrm{C} 3 \mathrm{H} / \mathrm{HeM}$ mouse. AP-18 cells exhibit fibroblast-like morphology, slow growth, and contact inhibition. The doubling time of AP-18 cells is 50-60 h, which is about 2-fold longer than that of well-known 3T3-L1 cells derived from mouse embryos. A small population of AP-18 cells spontaneously differentiates into adipocytes by 8 days after confluence, as judged by the accumulation of triglyceride droplets. Treatment of confluent AP-18 preadipocytes with adipogenic agents, containing dexamethasone, 3-methyl1-isobutylxanthine, and insulin, increased triglyceride contents about 5-fold compared to the contents in untreated cells. We also analyzed mRNA expression profiles for key transcription factors involved in adipocyte differentiation, peroxisome proliferator-activated receptor (PPAR) $\gamma$ and the CCAAT/enhancer binding protein (C/EBP) family, and for differentiation markers, aP2, adipocyte-specific fatty acid-binding protein and adipsin, adipocyte-specific serine protease. AP-18 preadipocytes express mRNAs for $\mathrm{C} / \mathrm{EBP} \beta, \mathrm{C} / \mathrm{EBP} \alpha$, PPAR $\gamma$, and aP2 before differentiation, but not adipsin mRNA. Expression of aP2 mRNA was increased in fully differentiated AP-18 cells. Likewise, expression of adipsin mRNA was increased after induced differentiation of AP-18 cells and reached the highest level in fully differentiated adipocytes. Thus, differentiation of AP-18 cells is associated with the increased expression of aP2 and adipsin mRNAs. The newly established AP-18 cell line provides a useful model for investigating adipocyte differentiation and adipogenesis.

- preadipocyte; mouse; proliferation; differentiation; adipogenesis

(C) 2005 Tohoku University Medical Press

The first cell lines capable of differentiating into adipocytes were derived from the established murine $3 \mathrm{~T} 3$ cell line. These lines, 3T3-L1 and 3T3-F442A, were derived from immortalized embryonic fibroblast cells of mesenchymal origin and are morphologically indistinguishable from fibroblasts (Green and Meuth 1974; Green and Kehinde 1975, 1976). Other preadipocyte cell lines have also been studied, including Ob1771 and HGFu (Negrel et al. 1978; Forest et al. 1983).

Received March 14, 2005; revision accepted for publication August 26, 2005.

Correspondence: Hideyuki Doi, M.D., Division of Advanced Surgical Science and Technology, Graduate

School of Medicine, Tohoku University, Seiryomachi, Aoba-ku, Sendai 980-8574, Japan.

e-mail:dovaline@mail.tains.tohoku.ac.jp 
Confluent preadipocyte cells differentiate into mature fat cells if dexamethasone (DEX) and 3-methyl-1-isobutylxanthine (MIX) are added to culture-medium which has been supplemented with insulin and fetal calf serum (FCS) (Rubin et al. 1978).

The process of adipocyte differentiation has been the focus of extensive research, and a cascade of transcriptional factors responsible for adipose conversion has been identified. In these adipocyte-differentiation model systems, the expression of CCAAT/enhancer binding protein $(\mathrm{C} / \mathrm{EBP}) \beta$ and $\mathrm{C} / \mathrm{EBP} \delta$ is upregulated at an early stage in response to DEX, MIX and insulin (MacDougald and Lane 1995; Darlington et al. 1998), followed by an increase in $\mathrm{C} / \mathrm{EBP} \alpha$ and peroxisome proliferator-activated receptor (PPAR) $\gamma$ expression, which activate or enhance the expression of adipocyte-specific genes including insulin-responsive glucose transporter (Glut 4), fatty acid-binding protein aP2, and stearoyl-CoA desaturase 1 (SCD1) (Spiegelman et al. 1993). Adipsin is a serine protease whose cDNA was isolated by differential screening of preconfluent and differentiated 3T3L1 cells (Cook et al. 1987). The phenotype of a mature adipocyte is defined by the expression of adipocyte-specific markers such as adipsin and aP2 (Bernlohr et al. 1984; Cook et al. 1985a, 1985b).

In normal adult animals, preadipocytes isolated from various adipose deposits are considered to have different adipogenetic potentials. Such differences may have major clinical consequence in humans, since visceral adiposity, compared with subcutaneous adiposity, is more strongly linked to insulin resistance, type 2 diabetes, hypertension, and dyslipidemia (Reaven 1988). In order to analyze the properties of preadipocytes and adipocytes in normal adult tissues, the establishment of preadipocyte cell lines derived from different normal tissues is a necessary step, but few preadipocyte cell lines derived from normal adult tissues have been established up to now. In the present study, we descrive the establishment and characterization of AP-18, a preadipocyte cell line, derived from normal adult subcutaneous fat.

\section{Materials and Methods}

Animals and reagents

This study was conducted in accordance with the policies of the Institute for Animal Experimentation of the Tohoku University Graduate School of Medicine. $\mathrm{C} 3 \mathrm{H} / \mathrm{HeNCrlBR}$ female mice were obtained from a pathogen-free colony maintained by Charles River, Yokohama, Japan. Tissue culture agents and TRIzol Reagent were purchased from Invitrogen (Carlsbad, CA, USA). DEX, insulin, MIX, Con A, and indomethacin were obtained from Sigma Chemical Co. (St. Louis, MO, USA). Agarose and ZetaProb membrane were purchased from Bio-Rad Laboratories (Hercules, CA, USA). $[\alpha-32 \mathrm{P}]$ deoxy-CTP and random primed labeling kits were obtained from the Amersham Co. (Arlington Heights, IL, USA) and Boehringer Mannheim (Indianapolis, IN, USA), respectively. The Triglyceride E test and other chemicals were purchased from Wako Pure Chemical Industries, Ltd. (Osaka).

\section{Cell culture}

Epidermal cell suspensions were prepared from mouse ear skin after a 24-hr incubation with $0.5 \%$ trypsin in phosphate-buffered saline (PBS) at $4^{\circ} \mathrm{C}$. The cells were then plated in 96-well plates in complete RPMI 1640 medium (Invitrogen), containing $5 \times 10^{-5} \mathrm{M}$ 2-mercaptoethanol, $1 \mu \mathrm{g} / \mathrm{ml}$ indomethacin, and $1 \mu \mathrm{g} / \mathrm{ml}$ Con A for 2 weeks and then propagated in medium without Con A and indomethacin for 3 months. After the first subculture, the cells were plated in 12-well plates (Becton Dickinson and Company, Franklin Lakes, NJ, USA) and grown as monolayer cultures in Dulbecco's modified Eagle's medium (DMEM) (Invitrogen) with L-glutamine and $4.5 \mathrm{~g} /$ liter glucose, and supplemented with $50 \mu \mathrm{g} / \mathrm{ml}$ penicillin, $100 \mu \mathrm{g} / \mathrm{ml}$ streptomycin, and $10 \%$ FCS at $37^{\circ} \mathrm{C}$ under $10 \% \mathrm{CO}_{2} /$ atmosphere. The serum-containing medium (SCM) was replaced every 3 days. Cultures were passaged at varying intervals for the first six months in culture, and regularly every 2 months thereafter. A mouse preadipocyte line, AP-18, was established, and is characterized by the accumulation of lipid droplets when a confluent monolayer is formed. The AP-18 clone was selected on the basis of efficient contact inhibition and a high frequency of differentiation into adipose cells at the confluent or resting stage. Cells were judged as confluent when no intercellular space or cell division could be observed under phase-contrast microscopy. When $2.5 \times$ $10^{4}$ cells were plated in one well of 12 -well plate, they grew into a confluent monolayer in 7 to10 days. The day 


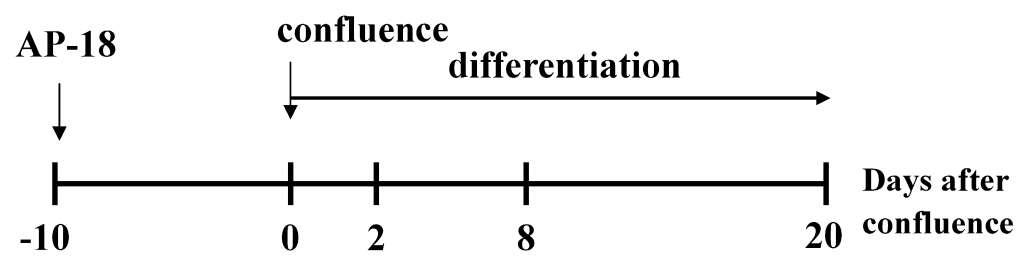

\section{Control cell culture}

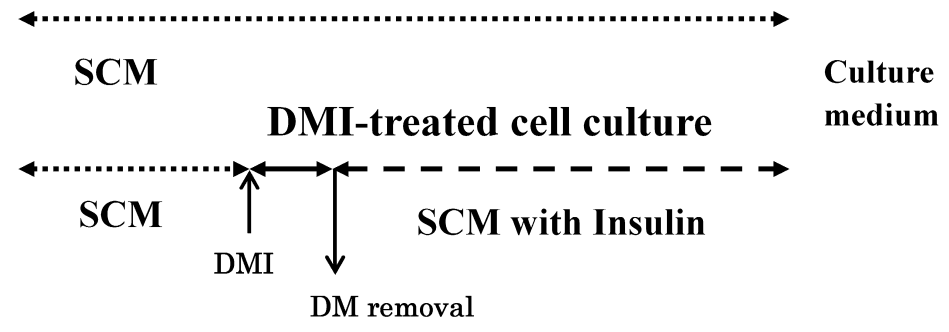

Fig. 1. Adipocyte differentiation protocol. AP-18 cells $\left(2.5 \times 10^{4}\right.$ cells $)$ were plated into 12 -well plates on day -10 , and grown in serum-containing medium (SCM). The day when preadipocyte cells reached confluence was defined as day 0 of adipocyte differentiation. On day 0 , confluent cells were induced to differentiate by supplementing SCM with $1 \mu \mathrm{M}$ DEX, $0.5 \mathrm{mM}$ MIX and $5 \mu \mathrm{g} / \mathrm{ml}$ insulin (DMI) from day 0 to day 2 . After 2 days, the supplemented medium was replaced with fresh SCM supplemented with insulin every third day during the experimental period.

when preadipocyte cells reached confluence was defined as day 0 for the adipocyte differentiation in vitro model. On day $0, \mathrm{AP}-18$ cells were induced to differentiate using previously decribed methods (Student et al. 1980). Briefly, the cells were cultured in SCM containing $1 \mu \mathrm{M}$ DEX, $0.5 \mathrm{mM}$ MIX, and $5 \mu \mathrm{g} / \mathrm{ml}$ insulin (DMI) from day 0 to day 2. After these 2 days, the medium was replaced with fresh SCM with insulin every 3 days during the experimental period (Fig. 1).

\section{Determination of cellular triglyceride content}

TG accumulation was measured by an organic extraction method previously described (Schwartz 1984). AP-18 cells in 60-mm culture plates were washed once with sterile phosphate-buffered saline and detached from the plates with $0.05 \%$ trypsin-EDTA. The cell suspension was sonicated for $10 \mathrm{~min}$ at $4^{\circ} \mathrm{C}$ and assayed for cellular TG content. Lipid was extracted and purified using the method of Folch et al. (1957). Cellular TG content was determined enzymatically using the Triglyceride E test (Wako Chemicals).

\section{RNA preparation and northern blot analysis}

To prepare RNA for northern blotting, cells were harvested at days $0,2,8$ and 20 during adipocyte differentiation. Total RNA was isolated from cultured preadi- pocytes using TRIzol Reagent. Homogenized samples in TRIzol Reagent were separated by adding $0.5 \mathrm{ml}$ chloroform. After centrifugation, the aqueous phase containing RNA was removed, and the RNA was precipitated with isopropanol. After washing with $80 \%$ ethanol, the RNA was solubilized in diethylpyrocarbonate-treated water. The RNA concentration was determined using UV absorbance: $260: 280$ ratios ranged from 1.8-2.0. Total RNA $(25 \mu \mathrm{g})$ was fractionated by electrophoresis on $1.0 \%$ agarose gels in $1.1 \mathrm{M}$ formaldehyde, and then transferred onto a ZetaProbe membrane. Membranes were prehybridized in hybridization buffer (25\% formaldehyde, 0.6 $\mathrm{M} \mathrm{NaCl}, 7$ mM Tris-HCl, pH 7.5, $0.6 \times$ Denhardt's solution, $0.0002 \%$ heat-denatured, sonicated salmon sperm DNA) for $30 \mathrm{~min}$ at $42^{\circ} \mathrm{C}$ and then hybridized with [ $\alpha$-32P] deoxy-CTP-radiolabeled DNA probes for $16 \mathrm{hr}$ at $42^{\circ} \mathrm{C}$ using a random primed labeling kit. The membranes were washed for $1.5 \mathrm{hr}$ with three changes of wash solution $\left(2 \times \mathrm{SSC}, 0.2 \times \mathrm{SCC}, 0.2 \times \mathrm{SCC}, 42^{\circ} \mathrm{C}\right)$. The blots were usually exposed with an intensifying screen to Fuji RX film (Fuji Photo Film Co., Ltd., Tokyo) for $1-3$ days at $-80^{\circ} \mathrm{C}$. Bands in the autoradiographic film of the probed membrane were densitometrically quantified and normalized using GAPDH as a control. cDNA was prepared by reverse transcription-polymerase chain reaction (PCR) using Superscript system 
(Invitrogen). The resulting cDNAs were amplified using sequence-specific primers with 30 cycles PCR $\left(94^{\circ} \mathrm{C}\right.$ for $1 \mathrm{~min}, 58^{\circ} \mathrm{C}$ for $1 \mathrm{~min}$, and $72^{\circ} \mathrm{C}$ for $1 \mathrm{~min}$ ). Primers corresponding to aP2, adipsin, $\operatorname{PPAR} \gamma, \mathrm{C} / \mathrm{EBP} \alpha$ and $\mathrm{C} / \mathrm{EBP} \beta$, were designed based on the published sequences, as follows: 5'-GATGCCTTTGTGGGAACC$3^{\prime}$ and $5^{\prime}$-AACTCTTGTGGAAGTCACG-3' for aP2 (Layne et al. 2001), 5'-ATGACGACTCTGTGCAGGTG$3^{\prime}$ and 5'-GTATAGACGCCCGGCTTTTT-3' for adipsin (Felmer et al. 2003), 5'-CCAGAGCATGGTGCCTTCGC TG-3' and $5^{\prime}$-GAGCTGACCCAATGGTTGCTG-3' for PPAR $\gamma, 5^{\prime}$-AGGTGCTGGAGTTGACCAGT-3' and 5'CAGCCTAGAGATCCAGCGAC- $3^{\prime}$ for $\mathrm{C} / \mathrm{EBP} \alpha$ (Han et al. 2001), and 5'-GGTTTCGGGACTTGATGCAATC-3' and 5'-CAACAACCCCGCAGGAACAT-3' for C/EBP $\beta$ (Christy et al. 1991). Hybridization to mouse cyclophilin and $\mathrm{B}$-actin probes (Invitrogen) was used as a control for RNA loading and integrity.

A

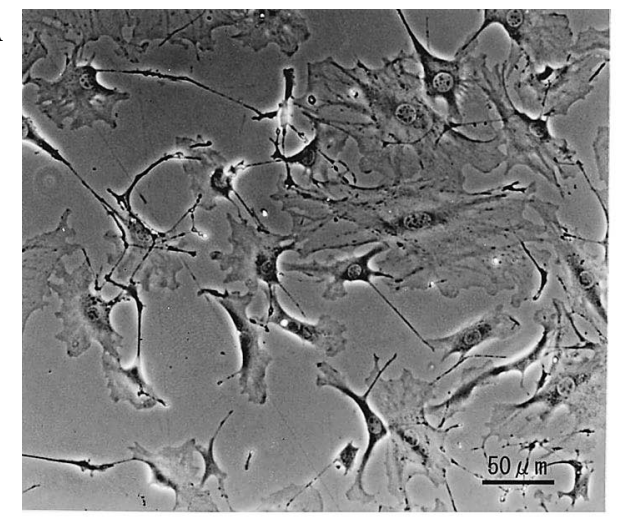

C

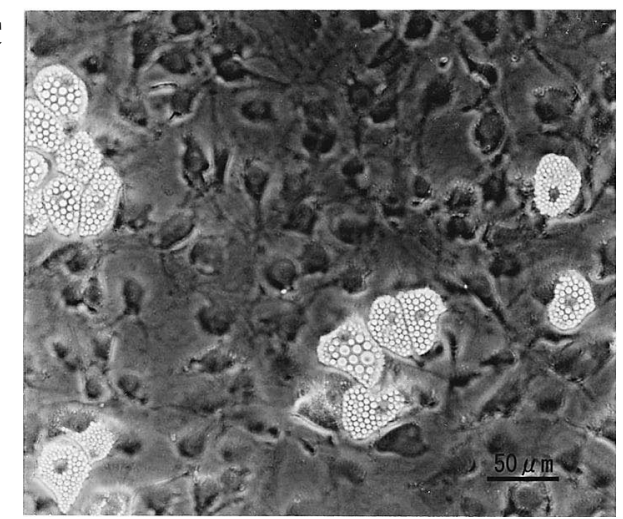

\section{Results}

Morphological characterization and growth characteristics of AP-18 cells in culture

A homogenous population of preadipocytes was isolated from a culture initiated from the ear skin of a female mouse. As shown in Fig. 2A, exponentially growing AP-18 cells exhibit a fibroblastic appearance with no lipid droplets. Fine projections on the cell surface and occasional intracytoplasmic vacuoles of small size were observed in this cell line under phase contrast microscopy. The doubling time for the cells in SCM was approximately 50 to $60 \mathrm{~h}$, whereas for 3T3-L1 cells the doubling time was approximately 22 h (Negrel et al. 1978). When AP-18 cells were cultured in SCM, cells grew into confluent monolayers in 7 to 10 days and remained in a
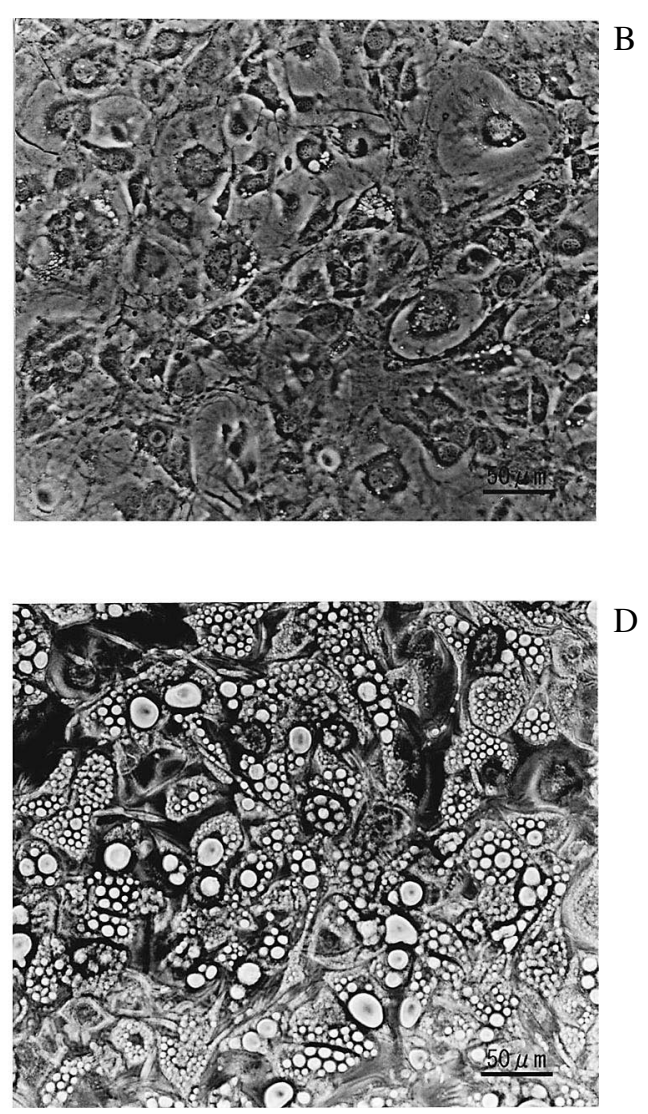

Fig. 2. Phase-contrast micrographs of AP-18 cells. A: Proliferating preadipocyte cells after subculture in SCM. B: Confluent cells after 6-7 days of culture in SCM. C: Some cells begin to show lipid droplets in their cytoplasm 14-20 days reaching confluence in SCM. D: Adipocyte differentiation was induced by treatment for 2 days with DMI as detailed in materials and methods (see Fig. 1). All scale bars represent $50 \mu \mathrm{m}$. 
contact inhibited resting state for two months (Fig. 2B). The number of confluent cells per well in the 12-well culture plates was approximately $1 \times$ $10^{5}$ cells and was constant even after 60 days in the wells. Changes in cell morphology were observed on days 14 to 20 after confluence. Cells showed a round shape and accumulated lipid droplets in their cytoplasm. When AP-18 cells were cultured for 20 days after confluence without adipogenic stimulation, only $10-20 \%$ of the cells in each well underwent differentiation into mature fat cells (Fig. 2C). The number of cells spontaneously differentiating into adipocytes, as well as the level and intensity of lipid deposition, was observed to vary slightly in each well.

Effects of isobuthylmethylxantine, dexamethasone and insulin on AP-18 preadipocyte differentiation

In order to determine whether AP-18 cells are able to differentiate into adipocytes following adipogenic stimulation, we analyzed morphological changes and of TG content in the cell cytoplasm. Beginning on day 0 after reaching confluence, treatment of AP-18 cells for 2 days with DMI resulted in an increased number of lipid-accumulating adipocytes on day 20 (Fig. 2D).
A concomitant increase in average TG content was observed in AP-18 cells when stimulated by adipogenic stimulation. The level of TG content in the stimulated cells was more than five-fold higher than that seen in the control cells cultured in SCM (Fig. 3).

\section{Expression of preadipocyte and adipocyte markers}

In order to determine whether AP-18 preadipocyte cells express $\mathrm{C} / \mathrm{EBP} \beta, \mathrm{C} / \mathrm{EBP} \alpha$ and PPAR $\gamma$ before adipocyte differentiation, we investigated the expression of these transcription factors in AP-18 cells cultured in SCM without adipogenic agents (Fig. 4). Expression of $\mathrm{C} / \mathrm{EBP} \beta$, $\mathrm{C} / \mathrm{EBP} \alpha$, and PPAR $\gamma$ mRNAs was detected on day 0 , and maintained at similar levels for up to 8 days. To explore whether the differentiation of AP-18 cells into adipocytes is associated with the transcriptional activation of adipocyte-specific genes, including aP2 and adipsin, we examined the time course of expression of these two mRNAs (Fig. 5). After AP-18 preadipocytes were grown to confluence in SCM, they were divided into two groups. One group of cells was remained in culture in SCM. Another group of cells was cultured for 2 days in the differentiation medium

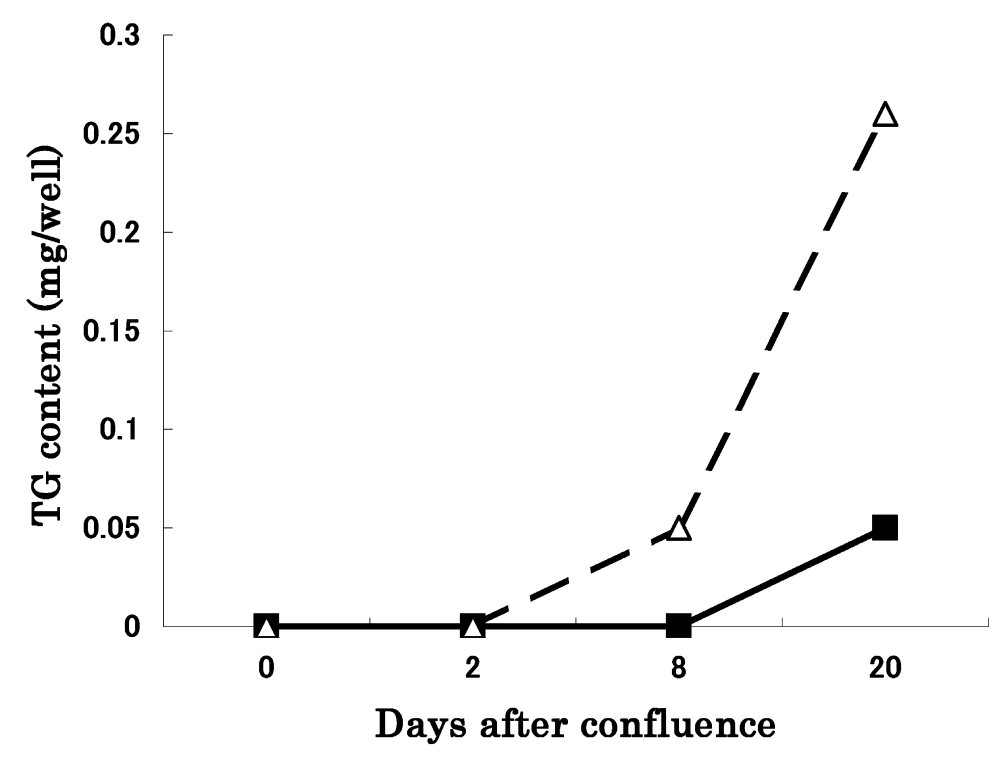

Fig. 3. Accumulation of TG during adipocyte differentiation of AP-18 cells.

$\square$, TG content of AP-18 cells cultured in SCM; $\triangle$, TG content of AP-18 cells treated for 2 days with DMI in SCM after confluence, and then cultured in SCM with insulin. 


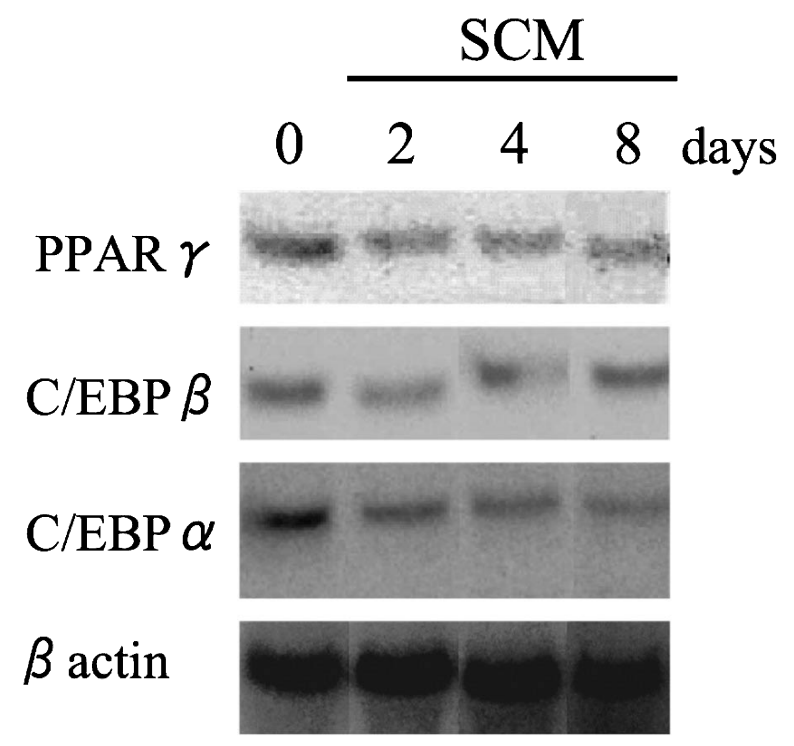

Fig. 4. Expression of PPAR $\gamma, \mathrm{C} / \mathrm{EBP} \beta$, and $\mathrm{C} / \mathrm{EBP}$ $\alpha$ mRNAs in AP-18 preadipocytes. Confluent AP-18 cells (day 0 ) were cultured in SCM without adipogenic stimulation. Total RNA was harvested from AP-18 cells at 0,2, 4 and 8 days after reaching confluence.

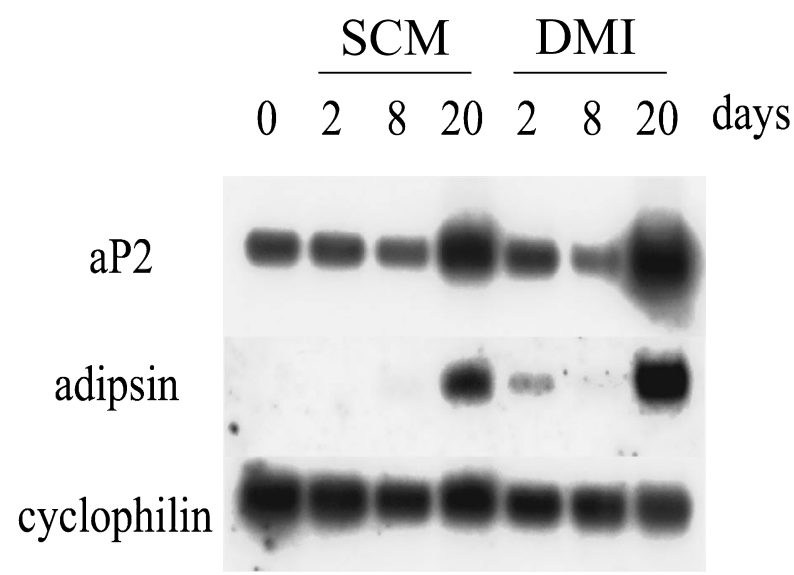

Fig. 5. Expression of adipocyte-specific mRNAs during adipocyte differentiation of AP-18 cells. The progress of differentiation was monitored by the expression of mRNAs encoding aP2 and adipsin. Total RNA was harvested from AP-18 cells cultured for up to 20 days in SCM with or without DMI.

containing DMI and then maintained in SCM with insulin. In both the untreated and DMItreated cells, the expression of aP2 mRNA was detected on 0 day, remained unchanged for up to
8 days, and rose to a plateau level on 20 days. In contrast, adipsin mRNA was undetectable in AP-18 preadipocytes cultured in SCM, and became detectable after 8 days of confluence. By 20 days, adipsin mRNA increased to a higher level, which may reflect spontaneous differentiation of AP-18 cells to adipocytes in SCM (see Figs. 2 and 3 ). In contrast, the addition of DMI led to the early appearance of adipsin mRNA on day 2 , and to the highest adipsin expression in fully differentiated AP-18 cells on day 20.

\section{Discussion}

In this study, we describe the establishment and characterization of a unique preadipocyte clonal cell line, AP-18, from the skin of a female adult mouse. To date, the AP-18 cells have undergone more than 60 passages and have shown no detectable changes under regular culture conditions. AP-18 cells, like other preadipocyte cell lines, stop proliferating when they form a confluent monolayer, and remain in a resting or contactinhibited state with no signs of growth for a long period. In cultures where cells remained confluent for several weeks in SCM, a small population of AP-18 cells began to accumulate lipid droplets spontaneously in their cytoplasm, even in the absence of adipogenic stimulation. Although cells from the AP-18 clonal line which convert to adipocytes with a high frequency were isolated from uncloned AP-18 stock, the original AP-18 culture contained some cells which accumulated lipid droplets after confluence, and others which did not. A similar potential for adipose cell formation was observed in 3T3-L1 cultures which had been maintained in a confluent state for several weeks in SCM (Green and Meuth 1974). When the 3T3-L1 cells were exposed to a combination of DEX, MIX and insulin for 2 days (day 0 to day 2), their transition to adipocytes was greatly accelerated (Student et al. 1980); lipid droplets fused together in the cells to make several large droplets or a single large central droplet surrounded by a thin rim of cytoplasm in each cell. In AP-18 cells, the accumulation of triglyceride occurred to some extent even in the absence of added insulin, and increased to a greater extent in the presence of 
adipogenic stimulation as seen in 3T3-L1 cells. The adipose conversion of AP-18 can be delayed indefinitely by keeping the cells in the exponential phase of growth, which is similar to the observation in 3T3-L1 cells. By definition, preadipocytes have passed through the commitment checkpoint in development and, when appropriately stimulated, differentiate into cells possessing the biochemical and morphological phenotype of adipocytes. In this context, AP-18 can be considered as an established clonal preadipocyte cell line. It is also noteworthy that the adult skin-derived AP-18 cells have a remarkably long generation time (doubling time, 50-60 h) when compared to that of the embryo-derived 3T3-L1 cells (approximately $22 \mathrm{~h}$ ).

Adipocyte differentiation is a complex process involving the expression of a cascade of transcription factors and adipocyte-specific genes. Consistent with earlier studies done in 3T3-L1 cells (Cao et al. 1991), the mRNA encoding for $\mathrm{C} / \mathrm{EBP} \beta$ was detectable on day 0 in undifferentiated AP-18 cells and was also detected at day 8 . Previous studies demonstrate that the expression of $\mathrm{C} / \mathrm{EBP} \alpha$ is both necessary and sufficient for the differentiation of 3T3-L1 preadipocyte cells into adipocytes (Lin and Lane 1992, 1994; Hwang et al. 1996). PPAR $\gamma$ is predominantly expressed in adipose tissue, and is a key transcription factor for adipogenesis, which has been demonstrated by several gain- or loss-of-function experiments (Tontonoz et al. 1994b; Kubota et al. 1999; Rosen et al. 1999). These transcriptional factors regulating fat cell development were also identified in AP-18 cells. The expression of PPAR $\gamma$ and $\mathrm{C} / \mathrm{EBP} \alpha$ was not detected in 3T3-L1 cells to prior to their differentiation, and was first detected on day 2 after confluence, and increased levels were observed at day 8 , and remained at an unchanged level thereafter (Birkenmeier et al. 1989; Cao et al. 1991; Tontonoz et al. 1994a). However, these two genes were already detected in AP-18 cells on day 0 after confluence, and did not show increased expression levels after that. The induction of PPAR $\gamma$ and $\mathrm{C} / \mathrm{EBP} \alpha$ is thought to coordinate the expression of adipocyte-specific genes such as aP2, GLUT4 and SCD1 (Spiegelman et al. 1993). In AP-18, the early constitutive coexpression of PPAR $\gamma$ and $\mathrm{C} / \mathrm{EBP} \alpha$ might lead to the induction of expression of aP2 prior to differentiation. Adipsin is found in human plasma and is produced and secreted in vitro by human adipocytes and by differentiated 3T3-L1 cells (Kitagawa et al. 1989; Baldo et al. 1993), thus making this gene a marker for terminally differentiated adipocytes. Adipsin was not detected in undifferentiated AP-18 cells, however, it was expressed at day 8 after confluence without adipogenic stimulation, or at day 2 when the induction protocol was initiated. An increase in adipsin mRNA on day 20 was closely associated with morphological changes, such as alteration in cell shape and the accumulation of large quantities of lipid. This suggests that the differentiation of AP-18 cells into adipocytes might be scored using the expression of this adipocyte-specific gene.

In summary, differentiated AP-18 cells can be identified as adipocytes by their morphology, their ability to accumulate lipid, and the expression of characteristic pre-adipocyte or adipocytespecific genes, including the strictly tissuespecific genes adipsin and aP2. AP-18 cells appear to have two advantages as an in vitro model of preadipocyte differentiation. First, AP-18 cells can be grown for many generations or passages in culture without the changes their morphology, in their slow growth rate, and their ability to differentiate into adipocytes. Second, AP-18 cells, isolated from the subcutaneous fat tissue of normal adult mouse, can be used as a starting point to search for differences in the gene expression of adipose cells from different tissues, and to elucidate the mechanism of subcutaneous adipocyte generation.

\section{References}

Baldo, A., Sniderman, A.D., St.-Luce, S., Avramoglu, R.K., Maslowska, M., Hoang, B., Monge, J.C., Bell, A., Mulay, S. \& Cianflone, K. (1993) The adipsin-acylation stimulating protein system and regulation of intracellular triglyceride synthesis. J. Clin. Invest., 92, 1543-1547.

Bernlohr, D.A., Angus, C.W., Lane, M.D., Bolanowski, M.A. \& Kelly, T.J., Jr. (1984) Expression of specific mRNAs during adipose differentiation: identification of an mRNA encoding a homologue of myelin $\mathrm{P} 2$ protein. Proc. Natl. Acad. Sci. USA, 81, 5468-5472. 
Birkenmeier, E.H., Gwynn, B., Howard, S., Jerry, J., Gordon, J.I., Landschulz, W.H. \& McKnight, S.L. (1989) Tissuespecific expression, developmental regulation, and genetic mapping of the gene encoding CCAAT/enhancer binding protein. Genes Dev., 3, 1146-1156.

Cao, Z., Umek, R.M. \& McKnight, S.L. (1991) Regulated expression of three $\mathrm{C} / \mathrm{EBP}$ isoforms during adipose conversion of 3T3-L1 cells. Genes Dev., 5, 1538-1552.

Cook, K.S., Groves, D.L., Min, H.Y. \& Spiegelman, B.M. (1985a) A developmentally regulated mRNA from 3T3 adipocytes encodes a novel serine protease homologue. Proc. Natl. Acad. Sci. USA, 82, 6480-6484.

Cook, K.S., Hunt, C.R. \& Spiegelman, B.M. (1985b) Developmentally regulated mRNAs in 3T3-adipocytes: analysis of transcriptional control. J. Cell Biol., 100, 514-520.

Cook, K.S., Min, H.Y., Johnson, D., Chaplinsky, R.J., Flier, J.S., Hunt, C.R. \& Spiegelman, B.M. (1987) Adipsin: a circulating serine protease homolog secreted by adipose tissue and sciatic nerve. Science, 237, 402-405.

Christy, R.J., Kaestner, K.H., Geiman, D.E. \& Lane, M.D. (1991) CCAAT/enhancer binding protein gene promoter: binding of nuclear factors during differentiation of 3T3-L1 preadipocytes. Proc. Natl. Acad. Sci. USA, 88, 2593-2597.

Darlington, G.J., Ross, S.E. \& MacDougald, O.A. (1998) The role of $\mathrm{C} / \mathrm{EBP}$ genes in adipocyte differentiation. J. Biol. Chem., 273, 30057-30060.

Felmer, R., Horvat, M. \& Clark, A.J. (2003) Overexpression of Raidd cDNA inhibits differentiation of mouse preadipocytes. Cell Prolif., 36, 45-54.

Folch, J., Lees, M. \& Sloane Stanley, G.H. (1957) A simple method for the isolation and purification of total lipides from animal tissues. J. Biol. Chem., 226, 497-509.

Forest, C., Grimaldi, P., Czerucka, D., Negrel, R. \& Ailhaud, G. (1983) Establishment of a preadipocyte cell line from the epididymal fat pad of the lean C57 BL/6J mouse-long term effects of insulin and triiodothyronine on adipose conversion. In Vitro, 19, 344-354.

Green, H. \& Meuth, M. (1974) An established pre-adipose cell line and its differentiation in culture. Cell, 3, 127-133.

Green, H. \& Kehinde, O. (1975) An established preadipose cell line and its differentiation in culture. II. Factors affecting the adipose conversion. Cell, 5, 19-27.

Green, H. \& Kehinde, O. (1976) Spontaneous heritable changes leading to increased adipose conversion in $3 \mathrm{~T} 3$ cells. Cell, 7, 105-113.

Han, J., Farmer, S.R., Kirkland, J.M., Corkey, B.E., Yoon, R., Pirtskhalava, T., Ido, Y. \& Guo, W. (2002) Octanoate attenuates adipogenesis in 3T3-L1 preadipocytes. J. Nutr., 132, 904-910.

Hwang, C.S., Mandrup, S., MacDougald, O.A., Geiman, D.E. \& Lane, M.D. (1996) Transcriptional activation of the mouse obese (ob) gene by CCAAT/enhancer binding protein alpha. Proc. Natl. Acad. Sci. USA, 93, 873-877.

Kitagawa, K., Rosen, B.S., Spiegelman, B.M., Lienhard, G.E. \& Tanner, L.I. (1989) Insulin stimulates the acute release of adipsin from 3T3-L1 adipocytes. Biochim. Biophys. Acta, 1014, 83-89.

Kubota, N., Terauchi, Y., Miki, H., Tamemoto, H., Yamauchi, T.,
Komeda, K., Satoh, S., Nakano, R., Ishii, C., Sugiyama, T., Eto, K., Tsubamoto, Y., Okuno, A., Murakami, K., Sekihara, H., Hasegawa, G., Naito, M., Toyoshima, Y., Tanaka, S., Shiota, K., Kitamura, T., Fujita, T., Ezaki, O., Aizawa, S., Nagai, R., Tobe, K., Kimura, S. \& Kadowaki, T. (1999) PPAR gamma mediates high-fat diet-induced adipocyte hypertrophy and insulin resistance. Mol. Cell, $\mathbf{4}$, 597-609.

Layne, M.D., Patel, A., Chen, Y.H., Rebel, V.I., Carvajal, I.M., Pellacani, A., Ith, B., Zhao, D., Schreiber, B.M., Yet, S.F., Lee, M.E., Storch, J. \& Perrella, M.A. (2001) Role of macrophage-expressed adipocyte fatty acid binding protein in the development of accelerated atherosclerosis in hypercholesterolemic mice. FASEB J., 15, 2733-2735.

Lin, F.T. \& Lane, M.D. (1992) Antisense CCAAT/ enhancer-binding protein RNA suppresses coordinate gene expression and triglyceride accumulation during differentiation of 3T3-L1 preadipocytes. Genes Dev., 6, 533-544.

Lin, F.T. \& Lane, M.D. (1994) CCAAT/enhancer binding protein alpha is sufficient to initiate the 3T3-L1 adipocyte differentiation program. Proc. Natl. Acad. Sci. USA, 91, 8757-8761.

MacDougald, O.A. \& Lane, M.D. (1995) Transcriptional regulation of gene expression during adipocyte differentiation. Annu. Rev. Biochem., 64, 345-373.

Negrel, R., Grimaldi, P. \& Ailhaud, G. (1978) Establishment of preadipocyte clonal line from epididymal fat pad of ob/ob mouse that responds to insulin and to lipolytic hormones. Proc. Natl. Acad. Sci. USA, 75, 6054-6058.

Reaven, G.M. (1988) Role of insulin resistance in human disease. Diabetes, 37, 1595-1607.

Rosen, E.D., Sarraf, P., Troy, A.E., Bradwin, G., Moore, K., Milstone, D.S., Spiegelman, B.M. \& Mortensen, R.M. (1999) PPAR gamma is required for the differentiation of adipose tissue in vivo and in vitro. Mol. Cell, 4, 611-617.

Rubin, C.S., Hirsch, A., Fung, C. \& Rosen, O.M. (1978) Development of hormone receptors and hormonal responsiveness in vitro. Insulin receptors and insulin sensitivity in the preadipocyte and adipocyte forms of 3T3-L1 cells. J. Biol. Chem., 253, 7570-7578.

Schwartz, J. (1984) Growth hormone directly alters glucose utilization in 3 T3 adipocytes. Biochem. Biophys. Res. Commun., 125, 237-243.

Student, A.K., Hsu, R.Y. \& Lane, M.D. (1980) Induction of fatty acid synthetase synthesis in 3T3-L1 pradipocytes. $J$. Biol. Chem., 255, 4745-4750.

Spiegelman, B.M., Choy, L., Hotamisligil, G.S., Graves, R.A. \& Tontonoz, P. (1993) Regulation of adipocyte gene expression in differentiation and syndromes of obesity/ diabetes. J. Biol. Chem., 268, 6823-6826.

Tontonoz, P., Hu, E., Graves, R.A., Budavari, A.I. \& Spiegelman, B.M. (1994a) mPPAR gamma 2: tissuespecific regulator of an adipocyte enhancer. Genes Dev., 8 , 1224-1234.

Tontonoz, P., Hu, E. \& Spiegelman, B.M. (1994b) Stimulation of adipogenesis in fibroblasts by PPAR gamma 2, a lipidactivated transcription factor. Cell, 79, 1147-1156. 